\title{
Federal Grant Fully Funds Small Turbine Installation at Maine Senior Housing Complex
}

\section{In March 2007, local agencies in Maine launched an effort to} reduce energy costs for residents of a subsidized elderly housing complex in Winter Harbor, resulting in a federal Residential Energy Assistance Challenge (REACH) grant that entirely funded the installation of a 10-kW Bergey Excel turbine.

MaineHousing, in conjunction with Efficiency Maine, the Washington-Hancock Community Agency (WHCA), and the town of Winter Harbor, proposed a small wind turbine on a 100-foot tower to power the common building at Millstream Heights Apartments, a subsidized elderly housing complex in Winter Harbor. The turbine would reduce energy costs for the tenants, $90 \%$ of whom are on a fixed income. The common building houses a community room and a laundry room.

No one anticipated the simple question that would delay the project: What is a wind turbine? Is it a structure, which would allow it to be regulated by the town's land use zoning ordinance? Or is it a tower that falls outside these regulations?

In April 2007, Winter Harbor Code Enforcement Officer John Fuhrman denied a building permit for the wind turbine after discussing the project with the Maine

\section{What Is a REACH Grant?}

Established in 1994, the annual federal REACH grant falls under the jurisdiction of the U.S. Department of Health and Human Services Low Income Home Energy Assistance Program (LIHEAP). The program was funded for the first time in 1996. States apply and compete for the REACH grant to fund energy-saving activities for people in "vulnerable households."

LIHEAP defines vulnerable households as those with very young children, people with disabilities, and older individuals in poor health.

Each year, REACH grants support projects that exhibit the "long-term, cost-effectiveness of supplementing energy assistance payments with non-monetary benefits that increase the ability of low-income households to meet home energy costs and achieve energy selfsufficiency."

To learn more about the REACH grant program, visit the LIHEAP Clearinghouse at www.liheap.ncat.org.

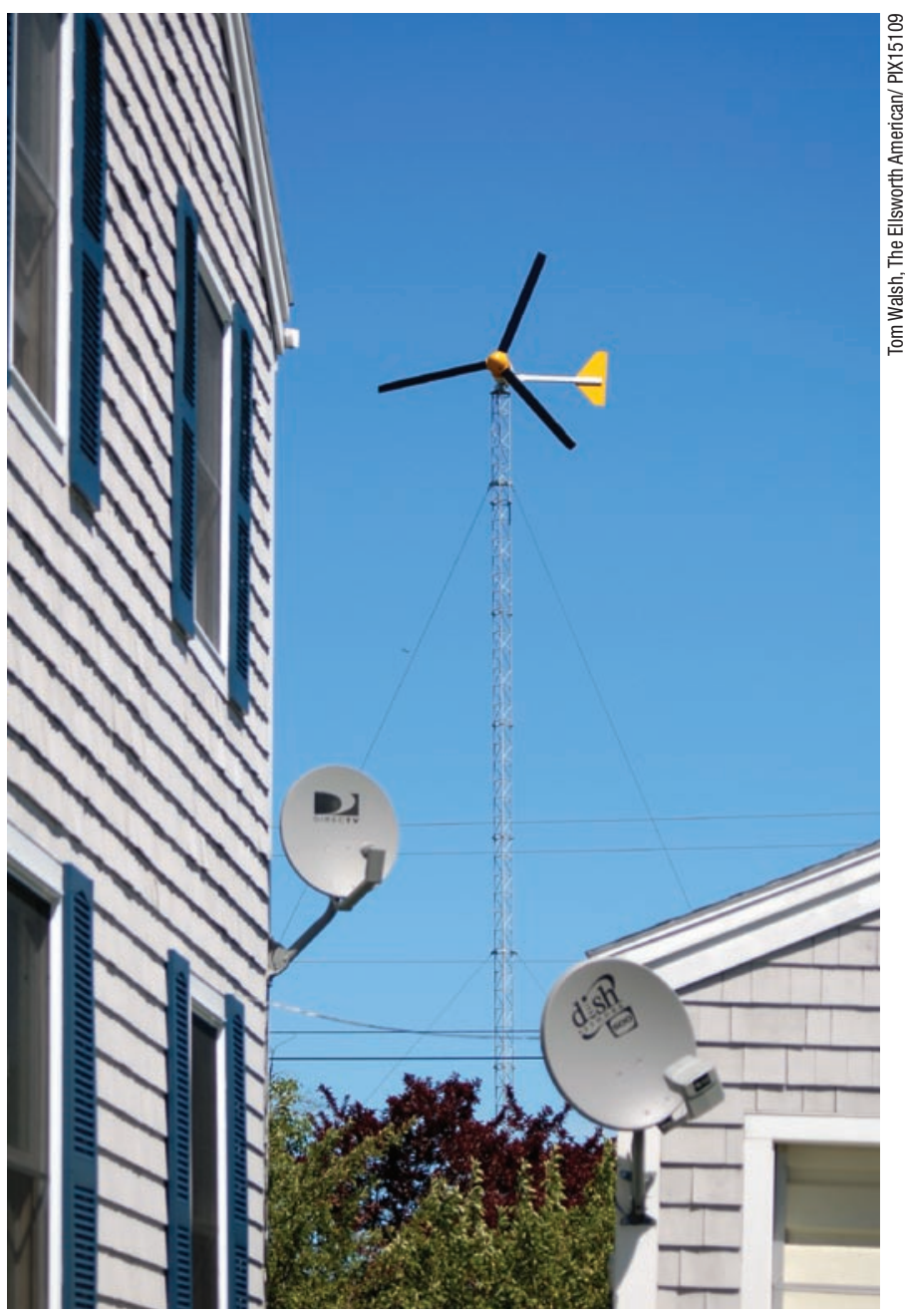

Completely funded by a federal Residential Energy Assistance Challenge (REACH) grant, a 10-kW Bergey Excel turbine generates electricity for the Millstream Heights Apartments, a subsidized elderly housing complex in Winter Harbor, Maine.

Municipal Association (MMA). In the MMA's opinion, the wind turbine was considered a structure because it would provide support (electricity) to the Millstream Heights residents. As a structure, the tower was subject to a 40 -foot height limitation.

At 40 feet, the tower would be equal in height to other structures within the Winter Harbor community, inhibiting the turbine's access to wind. The tower raises the turbine above the air turbulence that can exist close to the ground because of obstructions such as hills, buildings, and trees. And in general, the higher the tower, the more power 
the wind system can produce. In order to perform most efficiently, the turbine needed to be sited on a 100-foot tower.

At a June 7 hearing before the Winter Harbor Appeals Board, the decision to deny the building permit was contested. After listening to arguments from both sides, the board voted. In a 3-1 decision, it was decided that the wind turbine was not a structure regulated by Winter Harbor's land use zoning ordinance. The 100-foot wind turbine was approved.

According to Eleanor West, WHCA community services director, the issue of whether or not the wind turbine was considered a structure was the only major problem encountered by the WHCA throughout the entire process.

"The biggest difficulty was getting approved for the tower," West said.

West said that the wind turbine and tower cost $\$ 40,190$. The installation cost was $\$ 24,346$. The REACH grant covered the entire $\$ 64,536$ needed for the project, and a 3-year maintenance package was included in the deal.

According to Jo-Ann Choate, Energy Programs Manager at MaineHousing, the installation of the Bergey 10-kW XCEL wind turbine took a week and a half and was completed in August 2007. The Bergey XCEL has a 5-year warranty and is designed to last for 30-plus years.

Now that construction is complete, the amount of energy produced and the savings provided to the residents of Millstream Heights Apartments will be closely monitored.

"We're really going to be measuring and collecting data this winter to make sure we get the numbers correct," West said.

According to Choate, the projected savings will be approximately $\$ 200$ per month, although they will continue to evaluate it during the next year. Residents will see the savings after the evaluation period is complete.

"We can weatherize a home and make it tight, but that doesn't put money back into the pockets of lower-income people. These solutions are just band-aids, but with the REACH program, we're actually making a difference," West said.

And what do the townspeople think? A secondary concern among Winter Harbor residents was potential noise from the

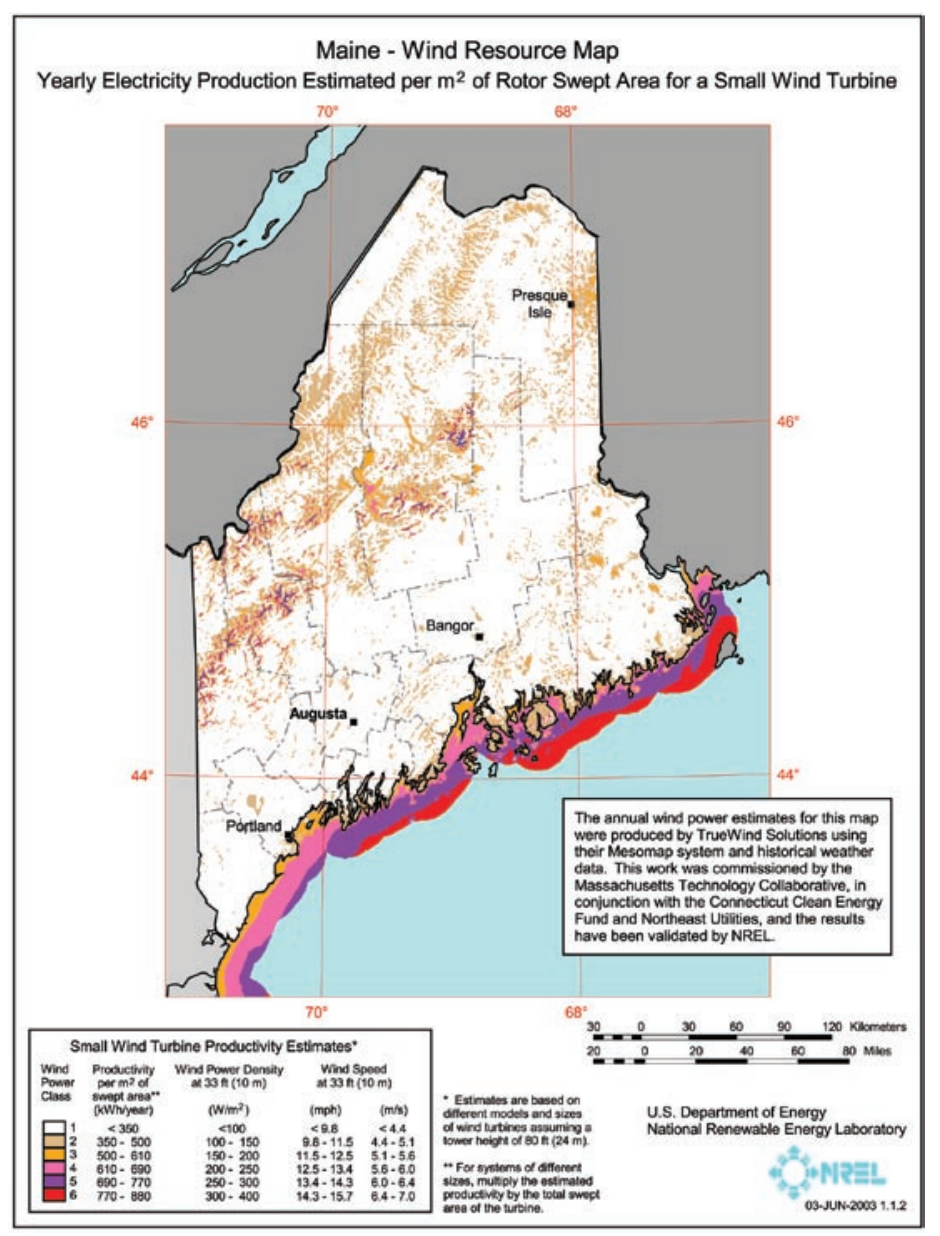

wind turbine. In March, the town held a meeting to reassure citizens. Now the turbine is running, and the residents of Winter Harbor can form their own opinions.

"There's no noise at all. It's no louder than a telephone signal," said Richard Fickett, whose firm Fickett Property Management manages Millstream Heights Apartments. More important, according to Fickett, no Millstream Heights residents have complained.

In fact, according to Fickett, the general reaction from the residents at Millstream Heights Apartments toward the wind turbine has been positive.

“They've been very receptive. They're pleased to see it tried as an alternative to help cut costs," Fickett said.

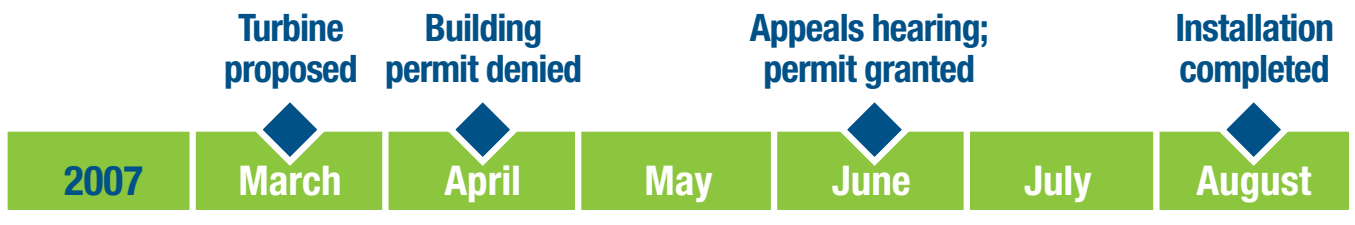

January 2008 • DOE/G0-102008-2508

A Strong Energy Portfolio for a Strong America

Energy efficiency and clean, renewable energy will mean a stronger economy, a cleaner environment, and greater energy independence for America. Working with a wide array of state, community, industry, and university partners, the U.S. Department of Energy's Office of Energy Efficiency and Renewable Energy invests in a diverse portfolio of energy technologies.
Produced for the U.S. Department of Energy by the National Renewable Energy Laboratory, a DOE national laboratory

Printed with a renewable-source ink on paper containing at least $50 \%$ wastepaper, including $20 \%$ postconsumer waste
For more information contact: EERE Information Center 1-877-EERE-INF (1-877-337-3463) www.eere.energy.gov 